\title{
Gene expression of multidrug-resistant ATP-binding cassette transporter (MDR1/ABCB1) in bovine mastitis
}

\author{
Mohammed Alquhaidan', Mahmoud Kandeel ${ }^{1,2 \star}$ \\ ${ }^{1}$ Department of Physiology, Biochemistry and Pharmacology, Faculty of Veterinary Medicine, King Faisal University, Alahsa \\ 31982, Saudi Arabia, ${ }^{2}$ Department of Pharmacology, Faculty of Veterinary Medicine, Kafrelsheikh University, Kafrelsheikh \\ 35255, Egypt
}

${ }^{*}$ For correspondence: Email: mkandeel@kfu.edu.sa; Tel: +966-568918734

Sent for review: 19 August 2018

Revised accepted: 23 November 2018

\begin{abstract}
Purpose: To investigate the expression of multidrug-resistant ATP binding cassette transporter Pglycoprotein (MDR1/ABCB1/P-gp) in mastitis and its correlation with the expression of apoptosis regulation.

Methods: Mastitic and normal mammary gland samples were collected after clinical examination and confirmed using field California mastitis test. Total RNA was extracted followed by cDNA synthesis and real-time $P C R$ to detect the expression pattern of $P$-gp. Tissue sections were examined for pathological changes and immune reactivity to the apoptotic regulator, Bcl-2-associated $X$ protein (BAX).

Results: Stained sections from mastitic samples showed congestion, infiltration of inflammatory cells and hemorrhage. Using immunohistochemistry, it was shown that mastitis is associated with overexpression of the apoptosis regulator, Bcl-2-associated $X$ protein $(B A X)$. There was increased expression of the pro-apoptotic factor, Bax, in mastitic alveolar lining and lactic tubules compared with normal mammary gland tissues. Using real-time PCR, the expression level of MDR1/ABCB1 was determined to be 2.6-fold higher in mastitic tissues than in normal mammary tissues.

Conclusion: Higher MDR1/P-gp level can modulate drug interventions by preventing intracellular accumulation of chemotherapeutics or anti-inflammatories via continuous efflux or export to extracellular fluids.
\end{abstract}

Keywords: ABC transporter, P-glycoprotein, Drug exporters, Mastitis, Mammary gland

\begin{abstract}
This is an Open Access article that uses a funding model which does not charge readers or their institutions for access and distributed under the terms of the Creative Commons Attribution License (http://creativecommons.org/licenses/by/4.0) and the Budapest Open Access Initiative (http://www.budapestopenaccessinitiative.org/read), which permit unrestricted use, distribution, and reproduction in any medium, provided the original work is properly credited.
\end{abstract}

Tropical Journal of Pharmaceutical Research is indexed by Science Citation Index (SciSearch), Scopus, International Pharmaceutical Abstract, Chemical Abstracts, Embase, Index Copernicus, EBSCO, African Index Medicus, JournalSeek, Journal Citation Reports/Science Edition, Directory of Open Access Journals (DOAJ), African Journal Online, Bioline International, Open-J-Gate and Pharmacy Abstracts

\section{INTRODUCTION}

ATP-binding cassette drug transporters (ABC transporters) comprise of a large set of proteins that are bound to cell membranes [1]. These proteins are ubiquitous and present in lower prokaryotes as well as in eukaryotes. $A B C$ transporters can be classified into importers or effluxers. The importers transport nutrients and other water-soluble molecules into the cells and are present only in prokaryotes, while effluxers or exporters expel the compounds to outside the cells and are present in both prokaryotes and eukaryotes [2].

Among the exporters, the multidrug resistant ABCB1 transporter, which is also known as Pglycoprotein (P-gp), is associated with 
multidrug resistance in cancers and microbial diseases [3]. P-gp expression was found to increase in multidrug resistant parasites such as leishmania [4], onchocerca [5], Plasmodium [6] and other parasites [7]. Furthermore, P-gp is associated with multidrug resistance in cancer cells and leads to failure of treatment due to lack of drug concentration inside cancer cells due to over-expression of P-gp [8]. The increased level of expression of P-gp was shown to correlate with insensitivity to the effect of drugs such as ivermectin and other macrocyclic lactones [9-11].

$A B C$ transporters are membrane bound proteins (Figure 1) composed of several domain comprising six transmembrane domains and ATP binding intracellular domains. The ATP binding domain catalyzes ATP hydrolysis during export of the substrates. During their activity in exporting the drug molecules to outside the cell, ATP is consumed, and ADP is released [12]. The wide variety of $A B C$ transporters is attributed corrected to the membrane spanning domains, which evolved independent of the ATP domain [2]. $A B C$ transporters change between two conformations called inward-outward open conformations. For exporting molecules, the substrate affinity is higher in the inward conformation and decreases the open conformation. After binding with the inwardshaped ABC transporter, the ATP binding domains interact and induce conformational changes that lead to outward opening of transmembrane domain and expulsion of substrates to outside the cells $[13,14]$.

The term binding cassette refers to the interaction of the two ATP binding domains with ATP position at the interface between these two domains (Figure 1). Each of the two ATP binding domains have a cavity to fit 1 ATP molecule. During efflux of substances, the two domains move to get in contact with each other at their ATP binding sites. Thus, the two ATP molecules appear to be sandwiched between the $A$ domains of $A B C$ transporters $[15,16]$. The substrate translocates to a certain path within $\mathrm{P}$ gp across its transmembrane domains to be exported to outside the cells (Figure 1).

Mastitis includes complex interactions and releases inflammatory mediators. MDR1/ABCB1 is a part of body defense mechanism to protect cells from damage by deleterious agents and exogenous toxins. Because mastitis is a common problem in veterinary field with an economic impact, the understanding of expression profile of MDR1/ABCB1 in udder affections needs to be significantly improved. Changes in
MDR1/ABCB1 expression level are expected to modulate the concentrations of intracellular signaling molecules and chemotherapeutic agents. In this study, the expression of MDR1/ABCB1 in normal and mastitic bovine udders and its associated pathological aspects and expression of pro-apoptotic factors were investigated.

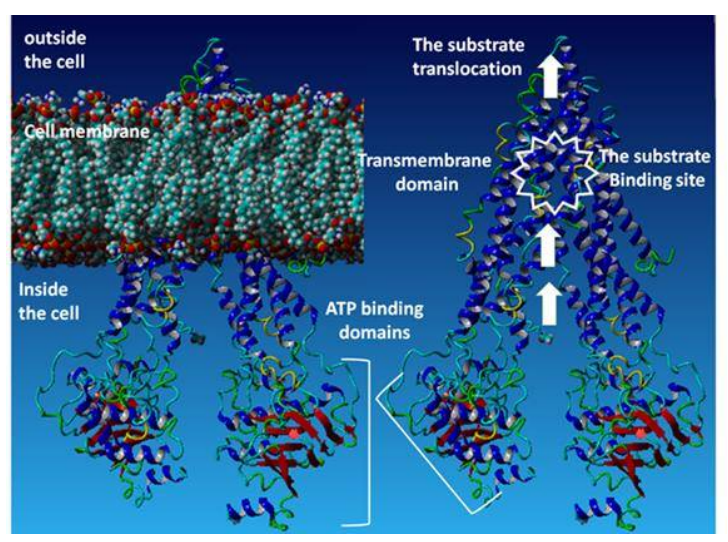

Figure 1: Structure of P-gp. During substrate recognition, it forms a $\mathrm{V}$-shaped structure facing the cytoplasm. The substrate-binding domain is within the transmembrane domains. P-gp exports drugs and toxins from inside to outside the cells through the translocation path across the cell membrane. The energy required for pumping the substrates is gained from hydrolysis of ATP that is bound with the ATP binding domains (The figure was produced by the authors using YASARA structure software, build number 14.12.2, License 2016, YASARA soft, Austria)

\section{EXPERIMENTAL}

\section{Collection of samples and experimental design}

Tissue samples from the mammary gland of Holestein cows were collected from Alomran abattoir in Alahsa, Saudi Arabia. In total, 20 samples (10 normal and 10 mastitic cows) were collected. History was acquired for every sample to check the reason of culling. Before slaughter, milk samples were collected from udders and checked using the California mastitis test (CMT). Score "0" was used when there was no change in the four wells of CMT paddle. In that case, the reason of culling was traced to confirm extraudder reasons such as facture, urogenital incompetence or other health problems. The samples from these udders were collected as normal udder tissues. Scores 1 - 3 indicate the degree of gel formation in CMT paddle and correspond to higher degree of mastitis. Positive clear and extensive gel formation from CMT were recorded as positive samples. Samples were preserved in RNA later solution, transferred to lab and kept at $-80^{\circ} \mathrm{C}$ until further analysis. For 
histopathological and immunohistochemical analyses, samples were stored in $10 \%$ formaldehyde. Animal experiments and sample collection were reviewed and approved by the research ethics committee, deanship of scientific research, King Faisal University, Saudi Arabia (approval no. 62599). Animal experiments were regulations of the science council of Japan [17].

\section{Sequence retrieval and design of P-gp real time primers}

The sequence of P-gp (accession no. AY789648) was retrieved from GenBank. P-gp was obtained using a pair of primers: forward primer 5'CGATGGCAAGGAAATAAAGCAGCTGA-3` and reverse primer 5'-GGCTGTTGTCTCCGTAGGC GATGTTC-3`. The primers were purified via HPLC to ensure maximum quality (Macrogen Inc., South Korea).

\section{RNA extraction}

Total RNA was extracted from tissue samples using the total RNA extraction kit (Qiagen Inc., USA) according to manufacturer instructions. The extracted RNA concentration was assessed using a spectrophotometric method.

\section{Production of cDNA}

cDNA was produced from total RNA using the cDNA synthesis kit (Invitrogen, CA, USA). First, RNA was incubated with BSA (1 $\mathrm{mg} / \mathrm{mL})$, RT primer and RNase-free water in a total volume of $6.0 \mu \mathrm{L}$. The mixture was incubated at $65^{\circ} \mathrm{C}$ for 5 $\mathrm{min}$. Then, $4 \mu \mathrm{L}$ of the second mixture containing Super Script TM III Reverse Transcriptase, DTT and RNase inhibitor was added, and incubation was continued at $55{ }^{\circ} \mathrm{C}$ for $1 \mathrm{~h}$. The cDNA synthesis was stopped by incubation at $70^{\circ} \mathrm{C}$ for 5 min. cDNA was quantified using the spectrophotometric method.

\section{Real time PCR}

The produced cDNA was used as a template to quantify the amount of the produced P-gp in udder tissues. The real time mixture contained $10 \mu \mathrm{L}$ of the 2x SYBR green master mix (Qiagen Inc., USA), $0.5 \mu \mathrm{L}$ of cDNA, $2 \mu \mathrm{L}$ of each primer (pmol) and RNase-free water up to $20 \mu \mathrm{L}$. Cycling conditions included denaturation for 8 min at $95^{\circ} \mathrm{C}$, followed by 40 amplification cycles: $10 \mathrm{~s}$ denaturation at $95^{\circ} \mathrm{C}, 30 \mathrm{~s}$ annealing at 57 ${ }^{\circ} \mathrm{C}$, and $10 \mathrm{~s}$ extension at $72{ }^{\circ} \mathrm{C}$. Quantitation was based on relative levels in comparison with glyceraldehyde-3-phosphate dehydrogenase (GADPH), as described previously [18]. The reaction was carried out in BioRad CFX96 Touch real time detection system. The analysis of mRNA expression data was performed using the CFX manager 3.1 software. Cycle threshold (CT) was used to compare MDR1 expression.

\section{Histopathology and immunohistochemistry (IHC)}

Fixed tissue samples were dehydrated and embedded in paraffin wax. Five $\mu \mathrm{m}$ sections were stained with $\mathrm{H} \& \mathrm{E}$. IHC was performed using streptavidin-biotin immunoperoxidase method.

First, tissue sections were deparaffinized and rehydrated followed by microwave exposure of antigens. $1 \%$ hydrogen peroxide was added, and the samples were incubated for 15 min to reduce the background and nonspecific staining due to endogenous peroxidase. Nonspecific staining was blocked using Ultra $\mathrm{V}$ block (Thermo Fisher, USA). Tissues were incubated with Bax primary antibody for antigen antibody reactions. Biotinylated goat anti-polyvalent antibody and streptavidin peroxidase were applied sequentially. 3.3'-diaminobenzidine peroxidase compatible chromogen was applied for detection. Then, the sections were counterstained with hematoxylin, dehydrated, and mounted. Negative control was produced using non-immune serum instead of reactive antibodies.

\section{RESULTS}

\section{Clinical and gross pathological findings}

Clinical exam of mastitic udder detected swelling, firmness and tenderness in the affected quarter. Cheesy or discolored fluid oozed from the lactiferous duct during sampling of mastitic udder. Highly reactive to CMT samples were considered as positive samples.

\section{Pathological examination}

Samples from positive clinical and CMT tests as well as normal udder samples were stained with $\mathrm{H} \& \mathrm{E}$ to confirm the status of udder before gene expression profiling of MDR1/ABCB1. The normal mammary gland tissue showed intact mammary alveoli and ducts and healthy interstitial blood vessels. Mastitic samples showed congested apparently dilated interstitial blood vessels, multiple areas of interstitial hemorrhage and cellular infiltration (Figure 2). In most of the examined sections, bacterial clumps, mostly cocci, were detected. The alveolar epithelium showed degeneration and sloughing. The interlobular tissue was swollen with hyperemic blood vessels. Occasionally, 
inflammatory cells, including mononuclear cells and leucocytes, were observed.

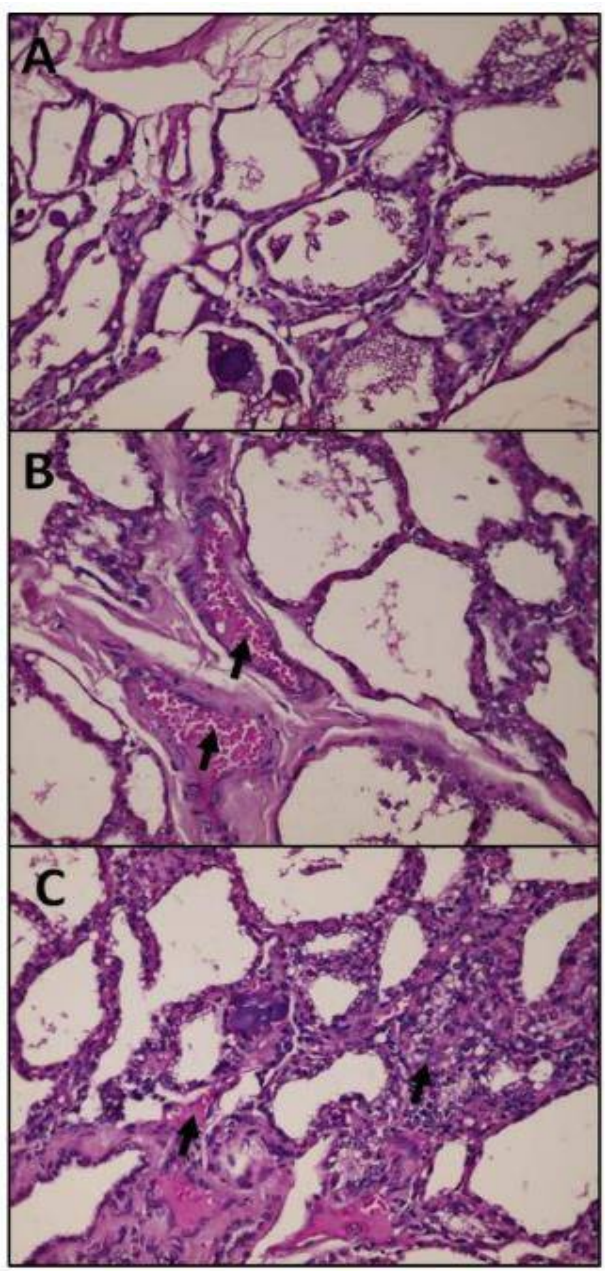

Figure 2: (A) Photomicrograph of the normal mammary gland tissue with normal interstitial blood vessels (H\&E, 400x). (B) Photomicrograph of the mammary gland showing congested, dilated interstitial blood vessels. (C) Photomicrograph of the mammary gland showing multiple areas of interstitial hemorrhage and cellular infiltration

\section{Gene expression of P-gp MDR1/ABCB1}

mRNA expression level of P-gp MDR1/ABCB1 in normal and mastitic tissues was measured using real time PCR. The expression level was normalized to the reference gene GADPH. The estimated levels were $0.23 \pm 0.09$ and $0.62 \pm$ 0.18 for normal and mastitic samples, respectively. This indicates a 2.6 -fold increase in the expression level of P-gp MDR1/ABCB1 in mastitic udder.

\section{Expression of pro-apoptotic factor, Bax}

The positive immune reactivity for Bax was identified by the presence of faint brown color in the lining of mammary gland alveoli and ductioles (Figure 3).

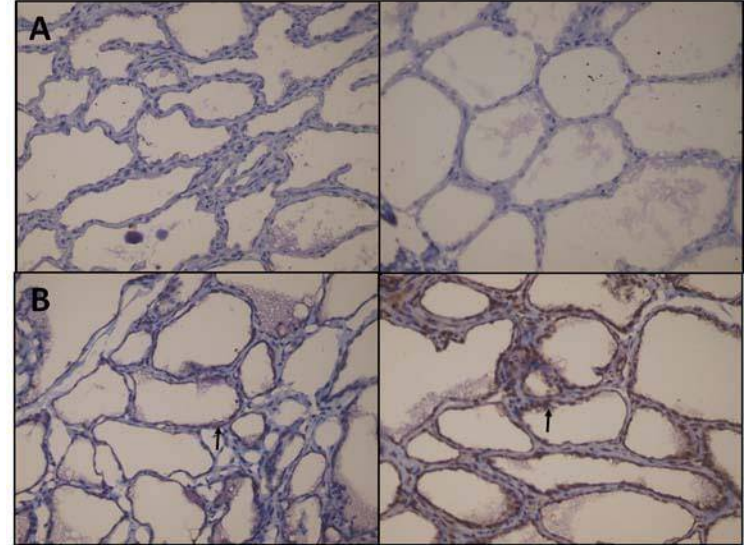

Figure 3: (A) Photomicrograph of the mammary gland showing negative Bax immunoreaction (400x). (B) A photomicrograph of the mammary gland showing faint positive Bax immunoreaction of the cells lining the ducts $(400 x)$

\section{DISCUSSION}

Multidrug resistant $A B C$ transporter is primarily composed of one monomer composed of two sets of transmembrane domains and two ATP binding domains. Drug resistance in cancers has been associated with expression of P-gp. Reversal of P-gp activity by inhibitors is a new strategy to minimize drug resistance [19]. ABC transporters have ability to export a wide range of hydrophilic and hydrophobic substances. Pglycoprotein forms $V$-shaped open conformation toward the inner site of the cell. Thus, this allows hydrophilic materials to be trapped directly in the active binding site. In addition, there is a gap in $A B C$ transporters at their membrane site to allow hydrophobic substances to be trapped directly in the active site $[20,21]$.

During mastitis, several interactive mediators are released that can modify a wide range of cellular proteins and membrane transporters. These changes have significant impact on drug disposition kinetics [22]. The overexpression of P-gp in mastitic tissue is expected to increase the efflux of drug to outside the udder cells and modulate their effect by increasing their extracellular concentration.

Apoptosis includes a series of complex interactions between cellular components and signaling molecules. The increased expression of pro-apoptotic factor Bax indicates increased apoptosis in mammary gland cells. Upregulation of Bax expression has been associated with programmed cell death of mouse mammary gland involution [23]. Bax accumulation precedes the activation of the apoptotic precursor Caspase-3 [24].

Trop J Pharm Res, December 2018; 17(12): 2338 
Positive Bax staining was detected in the alveoli and ductioles of the mammary gland. This agrees with the previous finding of $\mathrm{Bax}$ expression profile in bovine mammary gland [25]. Therefore, both pro-apoptotic markers and drug resistance exporters are upregulated in mastitis. Mastitic udder cells show higher expression of $\mathrm{P}$ gp MDR1/ABCB1. This may be a protective mechanism, which is characterized by pumping toxins and signaling mediators to outside the cells.

\section{CONCLUSION}

Mastitis is associated with a complex expression profile of mediators and proteins. Upregulation of P-gp MDR1/ABCB1 in mastitis may be a part of a protective defense mechanism. Over-expression of P-gp MDR1/ABCB1 has been associated with the apoptotic regulator, Bax. Higher Bax levels may induce the overexpression of P-gp to protect the cells from toxic chemicals and inflammatory mediators that are released during inflammation.

\section{DECLARATIONS}

\section{Acknowledgement}

This work was supported by the King Abdulaziz City for Science and Technology (KACST), Kingdom of Saudi Arabia under Graduate Research Program (Project no. 1-17-04-0040002).

\section{Conflict of interest}

The authors declare that they have no conflict of interest with regard to this work.

\section{Authors' contribution}

We declare that this work was performed by the authors named in this article, and all liabilities pertaining to claims relating to the content of this article will be borne by the authors. MA and MK designed the experiment, MA carried out the experiment, MA and MK wrote the paper, MA and MK approved the submission.

\section{REFERENCES}

1. Ward AB, Szewczyk P, Grimard V, Lee CW, Martinez L, Doshi $R$, Caya A, Villaluz $M$, Pardon E, Cregger $C$, Swartz DJ et al. Structures of P-glycoprotein reveal its conformational flexibility and an epitope on the nucleotide-binding domain. Proc Natl Acad Sci U S A 2013; 110(33): 13386-13391.
2. Davidson AL, Dassa E, Orelle C, Chen J. Structure, function, and evolution of bacterial ATP-binding cassette systems. Microbiol Mol Biol Rev 2008; 72(2): 317-364.

3. Ford JM, Hait WN. Pharmacology of drugs that alter multidrug resistance in cancer. Pharmacol Rev 1990; 42(3): 155-199.

4. Austrup J, Karanis P. Frequency of MDR1-related p-gp overexpression in Greek Leishmania isolates. Parasitol Res 2014; 113(3): 1225-1232.

5. Huang YJ, Prichard RK. Identification and stage-specific expression of two putative P-glycoprotein coding genes in Onchocerca volvulus. Mol Biochem Parasitol 1999; 102(2): 273-281.

6. Sanchez $C P$, Rotmann $A$, Stein WD, Lanzer $M$. Polymorphisms within PfMDR1 alter the substrate specificity for anti-malarial drugs in Plasmodium falciparum. Mol Microbiol 2008; 70(4): 786-798.

7. Lespine A, Ménez C, Bourguinat C, Prichard RK. Pglycoproteins and other multidrug resistance transporters in the pharmacology of anthelmintics: Prospects for reversing transport-dependent anthelmintic resistance. Int $J$ Parasitol Drugs Drug Resist 2012; 2: 58-75.

8. Chen $T$, Wang $C$, Liu $Q$, Meng $Q$, Sun $H$, Huo $X$, Sun $P$, Peng J, Liu Z, Yang $X$. Dasatinib reverses the multidrug resistance of breast cancer MCF-7 cells to doxorubicin by downregulating $P$-gp expression via inhibiting the activation of ERK signaling pathway. Cancer Biol Ther 2015; 16(1): 106-114.

9. Xu M, Molento M, Blackhall W, Ribeiro $P$, Beech $R$, Prichard $R$. Ivermectin resistance in nematodes may be caused by alteration of P-glycoprotein homolog. Mol Biochem Parasitol 1998; 91(2): 327-335.

10. Lespine A, Martin S, Dupuy J, Roulet A, Pineau T, Orlowski S, Alvinerie M. Interaction of macrocyclic lactones with P-glycoprotein: structure-affinity relationship. Eur J Pharm Sci 2007; 30(1): 84-94.

11. Ménez C, Mselli-Lakhal L, Foucaud-Vignault M, Balaguer $P$, Alvinerie $M$, Lespine $A$. Ivermectin induces $P$ glycoprotein expression and function through mRNA stabilization in murine hepatocyte cell line. Biochem Pharmacol 2012; 83(2): 269-278.

12. Jones $P$, George $A$. The $A B C$ transporter structure and mechanism: perspectives on recent research. Cell Mol Life Sci 2004; 61(6): 682-699.

13. Locher KP. Mechanistic diversity in ATP-binding cassette $(A B C)$ transporters. Nat Struct Mol Biol 2016; 23(6): 487-493.

14. Li W, Zhang $H$, Assaraf YG, Zhao K, Xu X, Xie J, Yang $D-H$, Chen Z-S. Overcoming ABC transporter-mediated multidrug resistance: Molecular mechanisms and novel therapeutic drug strategies. Drug Resist Updat 2016; 27: 14-29.

15. Moody JE, Millen L, Binns D, Hunt JF, Thomas PJ. Cooperative, ATP-dependent association of the nucleotide binding cassettes during the catalytic cycle of ATP-binding cassette transporters. J Biol Chem 2002; 277(24): 21111-21114.

Trop J Pharm Res, December 2018; 17(12): 2339 
16. Orelle C, Jault J-M. Structures and Transport Mechanisms of the ABC Efflux Pumps. In: EffluxMediated Antimicrobial Resistance in Bacteria. edn.: Springer; 2016; 73-98.

17. Ethics. http://wwwscjgojp/ja/info/kohyo/pdf/kohyo-20-k162epdf.

18. Livak KJ, Schmittgen TD. Analysis of relative gene expression data using real-time quantitative $P C R$ and the 2- $\triangle \Delta C T$ method. Methods 2001; 25(4): 402-408.

19. Kartal-Yandim M, Adan-Gokbulut A, Baran Y. Molecular mechanisms of drug resistance and its reversal in cancer. Crit Rev Biotechnol 2015: 1-11.

20. Dean M, Hamon Y, Chimini G. The human ATP-binding cassette $(A B C)$ transporter superfamily. J Lipid Res 2001; 42(7): 1007-1017.

21. Fung KL, Hunt RC, Kimchi-Sarfaty C, Gottesman MM. Genetic Polymorphisms of P-glycoprotein: Echoes of Silence. In: $A B C$ Transporters-40 Years on. edn.: Springer; 2016; 105-134.
22. Gips $M$, Soback S. Norfloxacin pharmacokinetics in lactating cows with sub-clinical and clinical mastitis. J Vet Pharmacol Ther 1999; 22(3): 202-208.

23. Metcalfe $A D$, Gilmore A, Klinowska T, Oliver J, Valentijn AJ, Brown R, Ross A, MacGregor G, Hickman JA, Streuli $\mathrm{CH}$. Developmental regulation of $\mathrm{Bcl}-2$ family protein expression in the involuting mammary gland. $J$ Cell Sci 1999; 112 (Pt 11): 1771-1783.

24. Zhang H, Heim J, Meyhack B. Redistribution of Bax from cytosol to membranes is induced by apoptotic stimuli and is an early step in the apoptotic pathway. Biochem Biophys Res Commun 1998; 251(2): 454-459.

25. Andreotti CS, Pereyra EAL, Sacco SC, Baravalle C, Renna MS, Ortega HH, Calvinho LF, Dallard BE. Proliferation-apoptosis balance in Staphylococcus aureus chronically infected bovine mammary glands during involution. J Dairy Res 2017; 84(2): 181-189. 